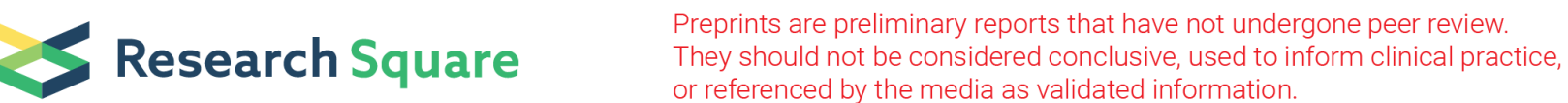

\section{Responses of Photosynthesis And Long-Term Water Use Efficiency To Ambient Air Pollution In Urban Roadside Trees}

\section{Mayu Matsumoto}

Kyoto Institute of Technology: Kyoto Kogei Sen'i Daigaku

Takashi Kiyomizu

Kyoto Institute of Technology: Kyoto Kogei Sen'i Daigaku

\section{Saya Yamagishi}

Kyoto Institute of Technology: Kyoto Kogei Sen'i Daigaku

\section{Tomomitsu Kinoshita}

Kyoto Institute of Technology: Kyoto Kogei Sen'i Daigaku

\section{Luisa Kumpitsch}

Kyoto Institute of Technology: Kyoto Kogei Sen'i Daigaku

\section{Atsushi Kume}

Kyushu University: Kyushu Daigaku

Yuko T. Hanba ( $\nabla$ hanba@kit.ac.jp )

Kyoto Kogei Sen'i Daigaku https://orcid.org/0000-0002-1537-262X

\section{Research Article}

Keywords: Stable carbon isotope discrimination, Maximum carboxylation rate, Stomatal limitation, Nitrogen oxide, Vehicle emissions

Posted Date: August 4th, 2021

DOI: https://doi.org/10.21203/rs.3.rs-713702/v1

License: (c) (1) This work is licensed under a Creative Commons Attribution 4.0 International License. Read Full License

Version of Record: A version of this preprint was published at Urban Ecosystems on February 12th, 2022. See the published version at https://doi.org/10.1007/s11252-022-01212-z. 


\section{Abstract}

We conducted on-site studies in Kyoto City, Japan, to evaluate the effect of air pollution by automobile gas exhaust on the leaf photosynthetic functions of four urban roadside tree species. Nitrogen oxides ( $\mathrm{NO}$ and $\mathrm{NO}_{2}$ ) are major air pollutants that are related to automobile gas exhaust. The species-specific response of leaf photosynthesis to air pollution was obtained for single-year data, in which at the high air pollution sites, Rhododendron $\times$ pulchrum, Rhaphiolepis indica, and Prunus $\times$ yedoensis had a higher restriction of maximum photosynthesis $\left(A_{\max }\right)$, while the opposite trend was obtained for Ginkgo biloba. When the data were pooled across the years from 2007 to 2019 in R. pulchrum, the dose-dependent effect of $\mathrm{NO}$ and $\mathrm{NO}_{2}$ on photosynthesis became obvious, in which they decreased $A_{\max }$ and increased the longterm leaf water use efficiency. A spatial variability map for $R$. pulchrum showed a lower $A_{\max }$ and higher water use efficiency at the heavy traffic areas in Kyoto City, which suggests that $R$. pulchrum increased tolerance to air pollution and water stress at the expense of the leaf photosynthesis. This study revealed the importance of the evaluation of the species-specific response of photosynthesis to air pollution for the efficient use of urban trees, even in regions with relatively low atmospheric pollution levels such as < $40 \mathrm{ppb}$ of $\mathrm{NO}$ or $\mathrm{NO}_{2}$.

\section{Introduction}

The urban environment imposes distinct multiple environmental stresses on trees compared to trees grown in non-urban areas. A high level of ambient air pollution caused by traffic exhaust (Van Wittenberghe et al. 2013; Iqbal et al. 2015), as well as urban water stress caused by less shade, the poor water permeability of paved roads, and the small volume of tree pits (Fini et al. 2009), imposes significant impacts on urban trees. Leaf photosynthesis is a key factor for the growth and survival of trees, and the sequestration of $\mathrm{CO}_{2}$ is the major role of urban trees (Nowak and Crane 2002). Therefore, tree species with high leaf photosynthesis are favorable as urban trees. However, the leaf photosynthetic function of trees is particularly sensitive to both air pollution (Dhir 2016) and water stress (Drake et al. 2017), in which the interspecific differences are remarkable.

Air pollution by traffic exhaust reduces photosynthesis in Pinues densiflora (Kume et al. 2000), Platanus occidentalis (Woo and Je 2006), and Rhododendron pulchrum (Kiyomizu et al. 2019), and increases photosynthesis in Ilex rotunda (Takagi and Gyokusen 2004), Acer rubrum (Lahr et al. 2018), and Ginkgo biloba (Kiyomizu et al. 2019). Such diverse responses are affected by species-specific responses to multiple air pollutants. Nitrogen oxides $\left(\mathrm{NO}\right.$ and $\left.\mathrm{NO}_{2}\right)$ are among the major air pollutants emitted as traffic exhaust, where previous laboratory exogenous applications of $\mathrm{NO}_{2}$ showed both negative (Hu et al. 2015) and positive effects (Wang et al. 2019) on the photosynthesis of urban trees. Although exogenous NO reduced leaf photosynthesis, NO has important roles in protection against the harmful effects of heavy metals (Procházková et al. 2013). Another important air pollutant ozone $\left(\mathrm{O}_{3}\right)$ imposes significant negative effects on the leaf photosynthesis of trees (Xu et al. 2019; Hoshika et al. 2020). Although urban roadside trees are expected to improve air quality by capturing particulate air pollutants, such as PM2.5 
(Grzędzicka 2018; Zhao et al. 2018), PM2.5 potentially reduces the leaf photosynthesis of urban trees; the heavy pollution of PM2.5 reduced the photosynthesis of a crop, wheat, up to $87 \%$ in wheat-planted farmland (Gu et al. 2018). However, the levels of both $\mathrm{O}_{3}$ and PM2.5 are not directly related to the amount of traffic (Hagenbjörk et al. 2017; Kiyomizu et al. 2019). $\mathrm{O}_{3}$ is both produced and destroyed by NO and $\mathrm{NO}_{2}$, which are the major air pollutants related to the amount of traffic (Hagenbjörk et al. 2017). The concentration of PM2.5 in the western part of Japan is strongly affected by PM2.5 from foreign sources, i.e., the relative contribution of foreign sources is estimated to be $50-60 \%$ (Ikeda et al. 2015).

Although the underlying physiological mechanisms for regulating the photosynthetic response to air pollution are still being studied, some new insights have been raised by recent studies. For the leaf photosynthesis, atmospheric $\mathrm{CO}_{2}$ is absorbed from the open stomata of the leaves, diffuses into the leaf mesophyll, and then is fixed to carbohydrates through biochemical reactions. The photosynthetic response to environmental variables is regulated by both stomatal and non-stomatal limitations, in which non-stomatal limitations are related to the leaf mesophyll anatomy and photosynthetic biochemistry (Flexas et al. 2012). Although the stomatal response has been expected as a key for the photosynthetic response to air pollution (Wittig et al. 2007), recent studies reported that for poplar and beech, the decline in photosynthesis caused by the atmospheric pollutant $\mathrm{O}_{3}$ is largely due to increased non-stomatal limitations (Xu et al. 2019; Hoshika et al. 2020). Further and more extensive studies are needed to clarify the species-specific effect of air pollution on the photosynthesis of urban trees and its underlying mechanisms.

In recent years, urban drought in summer has been accelerated through global and urban warming in the temperate zone (Savi et al. 2015; Meineke and Frank 2018). Therefore, efficient $\mathrm{CO}_{2}$ sequestration per water loss, e.g., high water use efficiency, is essential for the growth and survival of urban trees. Water use efficiency is used as a selection criterion for urban trees in Newcastle-upon-Tyne, UK (Grote et al. 2016). We focused on the leaf carbon isotope ratio, $\delta^{13} \mathrm{C}$, which is a suitable measure for the evaluation of spatial and temporal variation in long-term averaged water use efficiency (Kagotani et al. 2013; Brienen et al. 2017). In urban areas, leaf $\delta^{13} \mathrm{C}$ can be used as a metric of urban ecosystem services and has been used as an index of long-term water use efficiency in California, USA (McCarthy et al. 2011).

We conducted on-site studies in Kyoto City to evaluate the effect of air pollution on the leaf photosynthetic functions of urban roadside species. Study sites that had varied atmospheric pollution levels were selected. We used two sets of data. In the first data set, we evaluated the photosynthetic response to air pollution to clarify the underlying physiological mechanisms for the four major urban roadside trees in Japan, that is, two shrub trees Rhododendron $\times$ pulchrum and Rhaphiolepis indica, and two tall trees, Ginkgo biloba and Prunus $\times$ yedoensis. In the second data set, we focused on the most common shrub species, $R$. pulchrum. We analyzed the dependence of photosynthesis and water use efficiency on the atmospheric pollutants $\mathrm{NO}$ and $\mathrm{NO}_{2}$, using the annual averaged data from 2007 to 2019. The long-term photosynthetic water use efficiency of $R$. pulchrum was evaluated using the leaf carbon isotope ratio $\left(\delta^{13} \mathrm{C}\right)$. 
The main purposes of the present study were as follows: 1) to show how roadside trees in urban areas in Kyoto City are exposed to air pollution, 2) to compare the photosynthetic responses among the four major roadside tree species, $R$. pulchrum, $R$. indica, G. biloba, and $P$. yedoensis, and to clarify the contributions of stomatal and non-stomatal limitations to the photosynthetic response to air pollution, 3 ) to obtain the dependence of photosynthesis and water use efficiency on $\mathrm{NO}$ and $\mathrm{NO}_{2}$ in R. pulchrum, which is the most commonly used roadside tree species in Japan, and 4) to evaluate the spatial variability of photosynthesis and water use efficiency of $R$. pulchrum in the central part of Kyoto City and clarify the response of trees to the urban environment.

\section{Materials And Methods}

\section{Site description, air pollution levels, and tree species}

Kyoto City, Japan, is located in the Kyoto basin surrounded by mountains to the east, north, and west. The mean temperature, relative humidity, and cumulative precipitation during the growing season, from April to November, in an average year $(1981-2010)$ is $20.7^{\circ} \mathrm{C}, 66.0 \%$, and $1210 \mathrm{~mm}$, respectively. Concentrations of air pollutants have been monitored continuously by the Kyoto government at 14 monitoring stations in Kyoto City since 1970, in which the data are obtained every hour (http://www.nies.go.jp/igreen/td_down.html). We selected 21 study sites for collecting branches from roadside trees (Fig. 1a). The traffic data of $12 \mathrm{~h}$ of daytime were obtained for the years 2005, 2010, and 2015 from the Ministry of Land, Infrastructure, Transport and Tourism. The data were measured once a year at about 2000 sites in Kyoto Prefecture (https://www.mlit.go.jp/road/census/h17, h22-1, h27). We classified the 14 monitoring stations into three levels of pollution, low, medium, and high, using cluster analysis. The levels of air pollution of the study sites were determined by applying the pollution levels of the nearest monitoring stations.

We used four major tree species planted as roadside trees in Kyoto Prefecture in this study. The tree species used were two evergreen shrub trees, Rhododendron $\times$ pulchrum Sweet 'Oomurasaki' ( $R$. pulchrum, azalea) and Rhaphiolepis indica (L.) var. umbellata ( $R$. indica, yeddo hawthorn), and the two broadleaved deciduous tall trees, G. biloba L. (G. biloba, ginkgo) and Prunus $\times$ yedoensis Matsumura $(P$. yedoensis, cherry). $R$. pulchrum was the most common shrub species $\left(62.7 \times 10^{6}, 45 \%\right.$ of the shrub trees) planted in Japan in 2017 , followed by $R$. indica $\left(9.7 \times 10^{6}, 6.9 \%\right)$. G. biloba was the most common tall tree species $\left(5.5 \times 10^{5}, 8 \%\right)$, followed by $P$. yedoensis $\left(5.2 \times 10^{5}, 7.8 \%\right.$, lizuka and Funakubo 2018$)$. The leaves at the top of the crowns of $R$. pulchrum and $R$. indica trees are considered annual leaves after July because they are pruned annually between May and June, and after that, new annual leaves then subsequently expand. G. biloba and $P$. yedoensis trees are neither watered nor pruned during the growing season by the Kyoto government. The phenology of G. biloba and $P$. yedoensis is such that the leaves expand in early April, fully expand in May, begin senescence in late November, and fall in December.

\section{Leaf gas exchange measurements and photosynthetic limitations}


The study sites were selected such that they had as wide a range of traffic volumes as possible within one species in one sampling year. The longitude, latitude, and altitude of the study sites were $135^{\circ} 42^{\prime}-$ $49^{\prime}, 34^{\circ} 56^{\prime}-35^{\circ} 03^{\prime}$, and $20-80 \mathrm{~m}$, respectively. We selected $4-5$ trees at each study site, at which the mean tree heights were about 0.5-1 $\mathrm{m}$ for $R$. pulchrum and $R$. indica, and 5-7 $\mathrm{m}$ for G. biloba and $P$. yedoensis. Then, the branches of the roadside trees were collected from late May to early November. Sunlit healthy branches were harvested in the morning, from the tops of the canopies for R. pulchrum and $R$. indica and from the sunlit crowns for $G$. biloba and $P$. yedoensis, avoiding rainy days. These branches were excised from each individual tree at each site $(n=4-5)$. The ends of the branches were immediately immersed in water, brought back to the laboratory, and then photosynthesis measurements were performed for the healthy fully expanded mature leaves within $10 \mathrm{~h}$. Leaf photosynthesis was measured using a photosynthesis system constructed in our laboratory (in 2007, Kagotani et al. 2013) or using Li6400XT (Li-Cor, Lincoln, NE, USA, from the years 2014 to 2019), which had the same performance for leaf photosynthesis measurement. We previously confirmed that the leaf photosynthetic parameters of these four species were unchanged for $10 \mathrm{~h}$ after excision of the branches of the four tree species $(p>0.1, n=$ 4).

We obtained light-saturated photosynthesis $\left(A_{\max }\right)$ and stomatal conductance $\left(g_{\mathrm{s}}\right)$ at ambient $\mathrm{CO}_{2}$ of 400 $\mu \mathrm{mol} \mathrm{mol}{ }^{-1}$ and at $1000 \mu \mathrm{mol} \mathrm{mol}^{-1}$ of PPFD (in 2007) or at $1500 \mu \mathrm{mol} \mathrm{mol}^{-1}$ of PPFD (from 20142019). We confirmed that leaf photosynthesis was almost light-saturated at $1000 \mathrm{~mol} \mathrm{~mol}^{-1}$ for the four species, where the ratio to the maximum value was $94-95 \%$. The photosynthetic biochemical parameters, such as the maximum carboxylation rate $\left(V_{\text {cmax }}\right)$, were obtained from $A / C_{\mathrm{i}}$ curves (Ethier and Livingston 2004) using Li-6400XT (Kiyomizu et al. 2019; Kinoshita et al. 2021) for the years 2014 to 2019, where $C_{\mathrm{i}}$ means intercellular $\mathrm{CO}_{2}$. The measurements were conducted under $1500 \mu \mathrm{mol} \mathrm{mol}^{-1}$ of PPFD. In these photosynthesis measurements, the leaf temperature and vapor pressure deficit (VPD) were set at $26-28^{\circ} \mathrm{C}$ and $1.2-1.7 \mathrm{kPa}$, respectively. The stomatal and non-stomatal limitations were calculated using $A / C_{\mathrm{c}}$ curves obtained from the $A / C_{\mathrm{i}}$ curves, following a previous study (Grassi and Magnani 2005), where $C_{\mathrm{c}}$ means chloroplast $\mathrm{CO}_{2}$.

We measured the SPAD values as an indicator of leaf chlorophyll content (Parry et al. 2014), because high levels of air pollutants cause a decline in the leaf chlorophyll content (Joshi and Swami 2009), which is related to the photosynthetic biochemistry. SPAD values were evaluated for the leaves on which leaf gas exchange measurements were conducted, as mean values of the three replicated measurements. The SPAD value was measured using a SPAD meter (SPAD-502 Plus, Konica-Minolta, Tokyo, Japan).

The difference in annual climate should affect absolute values of leaf photosynthesis. To evaluate the effect of air pollution on the limitations of photosynthesis across the different years, photosynthesis values need to be 'normalized' using a reference of each year. We used the maximum value of $A_{\max }$ of each year for each species as a reference value $\left(A_{\text {ref }}\right)$, following a previous study (Grassi and Magnani 2005). The restriction in $A_{\max }$ in each year can then be estimated as follows: 
Restriction in $A_{\text {max }}=\left(A_{\text {ref }}-A_{\text {obs }}\right) / A_{\text {ref }}(1)$,

where $A_{\text {obs }}$ is the observed $A_{\text {max }}$.

\section{Carbon isotope discrimination}

After the photosynthesis measurements were finished, the leaves were dried at $60-70^{\circ} \mathrm{C}$ for $24 \mathrm{~h}$ using an oven (MOV-112, SANYO Electric, Osaka, Japan), and were stored in a desiccator at room temperature to analyze the leaf stable carbon isotope ratio $\left(\delta^{13} \mathrm{C}\right)$. Leaf carbon isotope discrimination, $\Delta^{13} \mathrm{C}$, is a good indicator of long-term leaf water use efficiency (Broeckx et al. 2014), which can be used for the evaluation of air pollution effects (Kagotani et al. 2013). $\Delta^{13} \mathrm{C}$ is determined as:

$\Delta^{13} \mathrm{C}(\%)=\left(\delta_{a}-\delta_{p}\right) /\left(1+\delta_{p} / 1000\right)(2)$,

where $\delta_{a}$ is the $\delta^{13} \mathrm{C}$ of atmospheric $\mathrm{CO}_{2}$ and $\delta_{p}$ is leaf $\delta^{13} \mathrm{C}$. We collected air samples of the study sites from 2007 to 2019 to obtain $\delta_{a}$, which depends on the air pollution level, and was used to calculate $\Delta^{13} \mathrm{C}$. Air samples of 2 liters near the tree canopies were collected in aluminum air bags using an air pump, and then $\delta_{a}$ was measured using an isotope mass spectrometer (Finnigan MAT 252, Thermo Fisher Scientific, MA, USA) or an isotope analyzer (G2101-i, Picarro, Inc., Santa Clara, CA, USA). The averaged values of $\delta_{a}$ were - 11.0 (0.3) \%o, - 11.7 (0.4) \%o, and - 12.0 (0.4) \%o for the low-, medium-, and high-pollution sites, respectively (mean (se), $n=14-23$ ). In the years 2007 and 2014, $\delta_{p}$ was measured using powdered leaf samples using the combined system of an elemental analyzer (EA1108, Carlo-Erba, Italy), interface (Conflo II, Thermo Fisher Scientific, MA, USA), and isotope mass spectrometer (Delta S, Thermo Fisher Scientific, MA, USA) at the Center of Ecological Research of Kyoto University corrected with standards (Tayasu et al. 2011). From 2015 to 2019, $\delta^{13} \mathrm{C}$ was measured using an elemental analyzer (Flash 1112 , Thermo Fisher Scientific, MA, USA), interface (Conflo IV, Thermo Fisher Scientific, MA, USA), and isotope mass spectrometer (delta V advantage, Thermo Fisher Scientific, MA, USA) at the Research Institute for Humanity and Nature.

To compare $\Delta^{13} \mathrm{C}$ values across the different years, we calculated deviations in the $\Delta^{13} \mathrm{C}$ value of each year using the maximum value as a reference $\left(\Delta^{13} \mathrm{C}_{\text {ref }}\right)$ :

Deviations in $\Delta^{13} \mathrm{C}=\Delta^{13} \mathrm{C}$ ref $-\Delta^{13} \mathrm{C}_{\text {obs }}(3)$,

where $\Delta^{13} \mathrm{C}_{\mathrm{obs}}$ is the observed $\Delta^{13} \mathrm{C}$. The larger deviations in $\Delta^{13} \mathrm{C}$ mean smaller $\Delta^{13} \mathrm{C}_{\mathrm{obs}}$, and in turn, higher long-term water use efficiency.

\section{The two data sets used in this study}

We used two sets of data for evaluation of the photosynthetic performance of urban trees. In the first data set, leaf gas exchange data for the four tree species G. biloba, P. yedoensis, R. pulchrum, and $R$. indica were used to obtain the species-specific response to air pollution. The photosynthesis 
measurements were performed in 2016 or 2017 for the leaves of four branches collected from the three six study sites, in which each species had one - two study sites of low-, medium-, and high-level air pollution $(n=4-8)$. Using the first data set, we compared the restrictions of photosynthesis, stomatal and non-stomatal limitations, and SPAD values that reflect the leaf chlorophyll content among these three pollution levels.

In the second data set, we focused on the species R. pulchrum for the evaluation of photosynthesis and water use efficiency in response to atmospheric $\mathrm{NO}$ and $\mathrm{NO}_{2}$ concentrations. The variation ranges in annual atmospheric $\mathrm{NO}$ and $\mathrm{NO}_{2}$ concentrations from 2007 to 2019 were from 0.4 to $47 \mathrm{ppb}$ and 6 to 37 $\mathrm{ppb}$, which are larger than the ranges within a year, from 0.7 to 17 and 6 to $19 \mathrm{ppb}$, respectively (Japan National Institute for Environmental Studies, http://www.nies.go.jp/igreen/td_down.html). We can detect the photosynthetic response of roadside trees to a wider range of $\mathrm{NO}$ and $\mathrm{NO}_{2}$ by using annual averaged data. The annual averaged values for the restriction of $A_{\max }$ and deviations in $\Delta^{13} \mathrm{C}$ were calculated using the data for the 4-35 leaves that were collected in 2007 and 2014-2019. Part of the second data set, the data for the years 2014 and 2015, were redrawn from the published data of our previous study (Kiyomizu et al. 2019). We obtained the dependence of leaf traits on $\mathrm{NO}$ and $\mathrm{NO}_{2}$ concentration for the pooled data.

Finally, we made a map of photosynthetic restrictions and deviation in $\Delta^{13} \mathrm{C}$ of $R \times$ pulchrum in Kyoto City, using the second data set, traffic volumes, and $\mathrm{NO}_{2}$ concentrations. First, the central part of Kyoto City, which is about $100 \mathrm{~km}^{2}$, including the study sites, was divided into areas of a $1 \mathrm{~km}^{2}$ mesh. We obtained 121 sections. Then, we obtained traffic volumes for each $1 \mathrm{~km}^{2}$ section using traffic volume data of the road census stations from 2015 (http://www.mlit.go.jp/road/census/). If multiple census stations were included in a $1 \mathrm{~km}^{2}$ section, the higher value was applied. Twenty three of the 121 sections $(19 \%)$ contained no census station, so the value of the nearest station was applied to these sections. Then, the $\mathrm{NO}_{2}$ concentration of each section was estimated using regression between the 12-h daytime traffic volumes and $\mathrm{NO}_{2}$ as in Fig. $1 \mathrm{e}(n=41)$ :

$\mathrm{NO}_{2}(\mathrm{ppb})=4.93+0.521 \times 12$-h daytime traffic volume $\left(10^{3}\right.$ cars $)(4)$.

Finally, restrictions of $A_{\max }$ and the deviation in $\Delta^{13} \mathrm{C}$ of each section were estimated using the correlations between $\mathrm{NO}_{2}$ and restriction of $A_{\mathrm{max}}$ or deviation in $\Delta^{13} \mathrm{C}$ in Fig. $3(n=17-19)$ :

Restrictions of $A_{\max }(\%)=16.7+1.48 \times \mathrm{NO}_{2}(\mathrm{ppb})(5)$,

Deviation in $\Delta^{13} \mathrm{C}(\%)=0.700+0.115 \times \mathrm{NO}_{2}(\mathrm{ppb})(6)$.

\section{Statistical analysis}

For the cluster analysis of the air monitoring stations, the data of nitrogen oxides $\left(\mathrm{NO}\right.$ and $\left.\mathrm{NO}_{2}\right)$ and traffic data for the years 2005, 2010, and 2015 were used, in which the traffic data of the nearest sites were applied to the air pollution monitoring stations. The $\mathrm{NO}$ and $\mathrm{NO}_{2}$ data used for the analysis were 
monthly means from April to November $(n=8)$. For the cluster analysis, the data of each year were normalized so the means and standard deviations were 1 and 0 , respectively. Differences in the photosynthetic traits among the three levels of pollution, low-, medium-, and high-level, were analyzed using analysis of variance (ANOVA) tested by Dunett's test, in which the values of low-level were treated as a control. The absolute values for the photosynthetic traits of each year were tested by two-way ANOVA, to evaluate the effect of pollution level and species. The dose-dependent effects of $\mathrm{NO}$ and $\mathrm{NO}_{2}$ on some leaf traits were analyzed using regression analysis. These statistical analyses were performed using EZR (Kanda 2013) and Rcmdr (ver. 2.7-1) for R software (R ver. 4.0.3).

\section{Results And Discussion}

\section{Atmospheric pollution levels in Kyoto City}

The levels of major atmospheric pollutants in Kyoto City from the years 2007 to 2019 (Table 1) showed that the daily and annual levels of $\mathrm{SO}_{2}$, from 2 to $8 \mathrm{ppb}$ and from 1 to $5 \mathrm{ppb}$, respectively, were low, and far below the environmental conservation standards, and furthermore, were much lower than the minimum dose for suppression of photosynthesis, $100 \mathrm{ppb}$ (Smith and Lytle 1997). The daily levels of atmospheric $\mathrm{NO}_{2}$ and fine particulate matter PM2.5, as well as the maximum of the hourly level of atmospheric $\mathrm{O}_{3}$, exceeded the environmental conservation standards in some cases. The annual values from 2007 to 2019 in the present study are not so different from those observed in Europe between 2000 and 2010, $\mathrm{NO}_{2}(0-12 \mathrm{ppb}), \mathrm{SO}_{2}$ (3 ppb), $\mathrm{O}_{3}(55 \mathrm{ppb})$, and PM2.5 (25 $\mathrm{gg} \mathrm{m}^{-3}$ ) (Jiang et al. 2020). The annual levels of nitrogen oxides $\left(\mathrm{NO}\right.$ and $\left.\mathrm{NO}_{2}\right)$ strongly correlated with the $12 \mathrm{~h}$-daytime traffic volumes, while the annual $\mathrm{SO}_{2}, \mathrm{PM} 2.5$, and $\mathrm{O}_{\mathrm{x}}$ did not (Table 1), which supports previous studies (Royal Society 2008; Kiyomizu et al. 2019). The ranges of the variations in PM2.5 and $O_{x}$ in Kyoto City were much smaller than those in daytime traffic, $\mathrm{NO}$ and $\mathrm{NO}_{2}$, which were indicated from the box plots and much smaller coefficients of variance (Fig. 1b). These results indicate that $\mathrm{NO}$ and $\mathrm{NO}_{2}$ are major air pollutants related to automobile gas exhaust in Kyoto City, and that the differences in photosynthetic responses among study sites in Kyoto City would be strongly affected by the levels of $\mathrm{NO}$ and $\mathrm{NO}_{2}$. 
Table 1

Ranges of air pollutant levels from 2007 to 2019 at the 14 monitoring stations, their environmental conservation standards in Kyoto City, and the results of regression analysis between the pollutant levels and $12 \mathrm{~h}$-daytime traffic volumes

\begin{tabular}{|c|c|c|c|c|}
\hline \multirow[t]{2}{*}{ Pollutant } & \multirow[t]{2}{*}{ Range of mean values } & \multirow[t]{2}{*}{$\begin{array}{l}\text { Environmental conservation } \\
\text { standard }\end{array}$} & \multicolumn{2}{|c|}{$\begin{array}{l}\text { Linear regression to } \\
12 \mathrm{~h} \text {-daytime traffic } \\
\text { volume }\end{array}$} \\
\hline & & & $r^{2}$ & $n$ \\
\hline \multirow[t]{2}{*}{$\mathrm{SO}_{2}(\mathrm{ppb})^{\mathrm{a})}$} & 2-8 (daily) & 20 (daily) & - & - \\
\hline & 1-5 (annual) & NA & $-0.099^{\text {n.s. }}$ & 12 \\
\hline \multirow[t]{2}{*}{ NO (ppb) } & 6-100 (daily) & NA & - & - \\
\hline & $1-36$ (annual) & NA & $0.61^{\star \star \star}$ & 28 \\
\hline \multirow{2}{*}{$\mathrm{NO}_{2}(\mathrm{ppb})$} & $18-50$ (daily) & 40 (daily) & - & - \\
\hline & 8-30 (annual) & NA & $0.58^{\star \star \star}$ & 28 \\
\hline \multirow{2}{*}{$\begin{array}{l}\text { PM2.5 }\left(\mu \mathrm{g} \mathrm{m}^{-}\right. \\
\text {3) b) }\end{array}$} & 19.3-42.8 (daily) & 35 (daily) & - & - \\
\hline & 8.5-18.1 (annual) & 5 (annual) & $0.0061^{\text {n.s. }}$. & 22 \\
\hline \multirow[t]{2}{*}{$\mathrm{O}_{\mathrm{x}}(\mathrm{ppb})^{\mathrm{c})}$} & $\begin{array}{l}43-136 \text { (max of hourly } \\
\text { values) }\end{array}$ & 60 (hourly values) & - & - \\
\hline & $28-40$ (annual) & NA & $-0.056^{\text {n.s }}$ & 18 \\
\hline \multicolumn{5}{|c|}{ 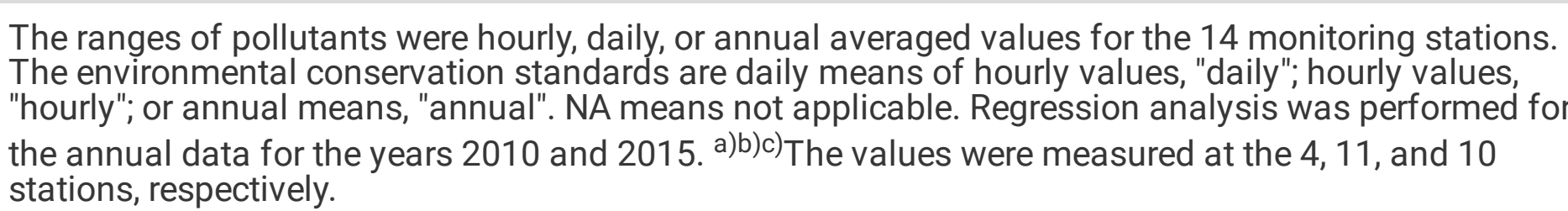 } \\
\hline
\end{tabular}

We then focused on the $\mathrm{NO}, \mathrm{NO}_{2}$, and daytime traffic, to classify the atmospheric pollution levels in Kyoto City. Cluster analysis revealed that the levels of atmospheric pollution at the 14 monitoring stations (Fig. 1a) were classified into three classes, high-, medium-, and low-pollution levels (Fig. 1c). Diurnal variations of air pollutants revealed that the trends were similar between $\mathrm{NO}$ and $\mathrm{NO}_{2}$, which showed peaks that corresponded to the trend in traffic volume in Kyoto City (Fig. 1d). However, the diurnal patterns in PM2.5 and $\mathrm{O}_{\mathrm{x}}$ were different from those of $\mathrm{NO}$ and $\mathrm{NO}_{2}$, in which the differences between pollution level (low, medium, and high) were much less clear compared to those for $\mathrm{NO}$ and $\mathrm{NO}_{2}$ (Fig. 1d). These results again indicate that among the atmospheric pollutants, $\mathrm{NO}$ and $\mathrm{NO}_{2}$ are important pollutants that strongly relate to the traffic volume. The $r^{2}$ values for linear regression between the 12-h daytime traffic volume and the annual levels of $\mathrm{NO} / \mathrm{NO}_{2}$ from April to November were $0.49-0.53$ for the data of 2005,2010 , and 
2015 (Fig. 1e). The strong dependence of $\mathrm{NO}_{2}$ on traffic volume supports our previous study (Kagotani et al. 2013) and the results reported in Beijing, China (Yang et al. 2019), indicating that areas with high traffic volumes in Kyoto City have high nitrogen oxide pollution. For the annual trends of these pollutants in Kyoto City, on the other hand, a significant reduction in $\mathrm{NO}$ and $\mathrm{NO}_{2}$ with time was observed in the years 2007 to 2019 , where the $\mathrm{NO}$ and $\mathrm{NO}_{2}$ levels in 2019 became $40-60 \%$ of those in 2007 for the three pollution levels (Fig. 1f). The historical decreasing trend in $\mathrm{NO}_{2}$ is in line with the reported decreasing trend of tropospheric $\mathrm{NO}_{2}$ vertical column density $\left(\mathrm{NO}_{2} \mathrm{VCD}\right)$ in Japan from 2000-2010, whereas the level of $\mathrm{NO}_{2}$ VCD in East Asia increased markedly in the same period (Itahashi et al. 2014).

\section{Restrictions of photosynthesis by air pollution in the four urban roadside tree species}

The ratio of atmospheric $\mathrm{NO}$ and $\mathrm{NO}_{2}$ concentrations compared to the low pollution sites were 4-20-fold and 1.5-2.1-fold, respectively, at the medium-pollution sites, and 15-50-fold and 2.7-3.9-fold, respectively, at the high-pollution sites (Fig. 2a). The restriction of maximum photosynthesis $\left(A_{\max }\right)$ was higher at the high-pollution sites than those at the low-pollution sites for $R$. pulchrum, $R$. indica, and $P$. yedoensis by $19-34 \%$ (Fig. 2b), which indicates that air pollution imposes a negative impact on the photosynthesis of these three species. In G. biloba, on the contrary, restrictions of $A_{\max }$ were less at the medium- and high-pollution sites compared to the low-pollution sites by $17-35 \%$. The contrasting results for R. pulchrum and G. biloba confirm our previous study obtained in autumn (Kiyomizu et al. 2019), which revealed that the photosynthetic response to urban $\mathrm{NO}$ and $\mathrm{NO}_{2}$ is highly species-specific, even under a relatively low level of $\mathrm{NO}_{2}$, below $50 \mathrm{ppb}$, which is generally observed in many cities including in East Asia (Kim and Guldmann 2015), Africa (Adon et al. 2016), Europe (Jiang et al. 2020), and the USA (Yli-Pelkonen et al. 2017).

The effects of air pollution on the restrictions of photosynthetic biochemical capacities, $V_{\text {cmax }}$ (carboxylation efficiency) and SPAD (reflects chlorophyll concentration), were overall in line with those of $A_{\text {max }}$, with the exception of $R$. indica at the high pollution site with a low restriction in SPAD (Table 2). These results confirm that the highly species-specific photosynthetic response to air pollution strongly depends on the biochemical trait. The higher restrictions in the SPAD value, i.e., the reduction in chlorophyll content under high atmospheric pollution, is reported in previous studies, in which a low chlorophyll content is often linked to a low photosynthetic performance (reviewed by Dhir 2016). 
Table 2

Restriction (\%) of the photosynthetic biochemical capacities $V_{\text {cmax }}$ and SPAD within a single year

\section{Species}

Parameter Pollution level R.pulchrum R.indica P.yedoensis G. biloba

Restriction of maximum carboxylation efficiency, $V_{\mathrm{cmax}}(\%)$

$\begin{array}{lllll}\text { Low } & 5.1(4.8) & 3.6(1.4) & 10.9(6.0) & 36.5(2.0) \\ \text { Medium } & 25.5(2.5)^{\star \star} & 28.1(2.7)^{\star \star \star} & 21.7(8.4) & 27.7(5.0) \\ \text { High } & 50.4(4.9)^{\star \star \star} & 21.6(3.0)^{\star \star} & 26.4(4.2) & 6.1(3.3)^{\star \star}\end{array}$

Restriction of SPAD, which reflects chlorophyll content (\%)

\begin{tabular}{lllll} 
Low & $10.8(3.9)$ & $18.2(0.8)$ & $5.9(2.7)$ & $21.7(6.2)$ \\
\hline Medium & $27.3(0.8)^{* \star *}$ & $31.6(0.9)^{* \star *}$ & $7.2(3.8)$ & $18.2(2.3)$ \\
\hline High & $30.4(3.3)^{* *}$ & $4.5(1.6)^{* \star *}$ & $17.9(1.5)^{*}$ & $3.3(1.1)^{* *}$
\end{tabular}

Values are means (se), in which restrictions were calculated as \% of the maximum value for each species $(n=4-16)$. The significance of the difference between pollution levels was tested by ANOVA, Dunnett's contrast, with data for the low pollution level treated as a control. The significance of the difference is shown as symbols ${ }^{\star} P<0.05,{ }^{* \star} P<0.01$, and ${ }^{* \star} P<0.001$. No symbol means no significant difference.

The analysis of photosynthetic limitations revealed that for all species, non-stomatal limitations were significantly larger than stomatal limitations $(p<0.05)$, in which the difference between non-stomatal and stomatal limitations at the high-pollution levels were larger for $R$. pulchrum, $R$. indica, and $P$. yedoensis (Fig. 2b). This indicates that non-stomatal factors are more important constraints than the stomata for leaf photosynthesis of these three urban tree species under high levels of $\mathrm{NO}$ and $\mathrm{NO}_{2}$. The importance of non-stomatal limitations for the reduction in photosynthesis by an air pollutant, $\mathrm{O}_{3}$, has been reported for poplar and beech (Xu et al. 2019; Hoshika et al. 2020). For G. biloba, on the other hand, the reduction in the difference between non-stomatal and stomatal limitations at the high-pollution levels (Fig. 2b) indicates less non-stomatal limitation at the high-pollution levels, which is partly related to anatomical alterations in the leaf mesophyll cells by air pollution (Hoshika et al. 2020). Our previous study reported an increase in the mesophyll thickness of G. biloba at high-pollution sites, which induces increases in both mesophyll $\mathrm{CO}_{2}$ diffusion and the biochemical capacities (Kiyomizu et al. 2019) that involves the reduction in non-stomatal limitations.

\section{Restrictions in photosynthesis and deviations in long-term water use efficiency in response to air pollution across the years}


We then focused on the major urban shrub species $R$. pulchrum, which had the highest restriction of photosynthesis (Fig. 2b) and lowest photosynthesis rate among the four species at high-pollution levels (Table S1). The relationship between atmospheric $\mathrm{NO}$ or $\mathrm{NO}_{2}$ and leaf traits across the years was analyzed using the pooled data from 2007 to 2019 (Fig. 3). Restrictions of $A_{\max }$ were increased with increasing $\mathrm{NO}$ or $\mathrm{NO}_{2}$ for $R$. pulchrum, which indicates that photosynthesis becomes more inhibited by higher atmospheric nitrogen oxides, which confirms our previous results (Fig. 1, Table 1). Additionally, two-way ANOVA revealed that there was a small interaction between year and pollution level on $A_{\max }$ (Table S2), which indicates that the effect of pollution level on these variables was overall held across the years.

Deviations in annual carbon isotope discrimination from the maximum value of each year became higher as $\mathrm{NO}$ or $\mathrm{NO}_{2}$ increased, i.e., $\Delta^{13} \mathrm{C}$ decreased with increasing nitrogen oxides (Fig. 3). This result confirms our previous study (Kiyomizu et al. 2019) and the study for Norway spruce in central Europe that reported decreased $\Delta^{13} \mathrm{C}$ with air pollution (Čada et al. 2016), which indicates that long-term water use efficiency becomes higher as nitrogen oxides increase (Kume et al. 2006). The evaluation of the effect of air pollution on long-term water use efficiency by using the leaf carbon isotope ratio $\left(\delta_{p}\right)$ can be difficult because of the opposite effect of fossil fuel $\delta^{13} \mathrm{C}\left(\delta_{a}\right)$ and $\Delta^{13} \mathrm{C}$ on $\delta_{p}$ (Eq. 2, Pataki et al. 2010). In fact, atmospheric $\mathrm{NO}_{2}$ imposes a positive effect (Kume et al. 2006) or no effect (Yang et al. 2018) on leaf $\delta^{13} \mathrm{C}$ $\left(\delta_{p}\right)$ of Pinus densiflora foliage in Japanese and Korean cities, respectively. In spite of these difficulties, we successfully obtained a clear trend of $\Delta^{13} \mathrm{C}$ in relation to atmospheric nitrogen oxides (Fig. 3) by both correction of the effect of fossil fuel $\delta^{13} \mathrm{C}$ and evaluation of relative changes in $\Delta^{13} \mathrm{C}$ (Eq. 2). The increase in long-term water use efficiency with the decrease in photosynthesis by nitrogen oxides in $R$. pulchrum suggests that at sites with high air pollution, stomatal closure becomes significant, which may contribute to reducing the absorption of atmospheric pollutants from the stomata, as well as to reduce water consumption. In this sense, $R$. pulchrum becomes more favorable when summer drought is more serious due to the effects of urban and global warming. The high water use efficiency has often been considered to be an advantageous trait in water-limited conditions (Medrano et al. 2009).

Finally, we performed mapping of the restriction of $A_{\max }$ and deviations in $\Delta^{13} \mathrm{C}$ for $R$. pulchrum in the central area of Kyoto City (Fig. 4), based on the relationships among the traffic volumes, $\mathrm{NO}_{2}$ level, and restriction of $A_{\max }$ or deviations in $\Delta^{13} \mathrm{C}$ (Figs. 1 and 3). The restriction of $A_{\max }$ of R. pulchrum was higher in the area near Kyoto Station, 50-60\%, compared to the northern or eastern part of Kyoto City, 20-30\% (Fig. 4a). Although the spatial distributions of vegetation in urban areas were reported using remotesensing in previous studies (Liu and Yang 2013; Zhong et al. 2019), few studies have shown the spatial distribution of gas exchange measurement-based photosynthesis in an urban area at this time. Our present study revealed that in some tree species, leaf photosynthesis is more strongly restricted at sites with higher traffic volumes in urban areas, indicating that such species have smaller production. From the viewpoint of $\mathrm{CO}_{2}$ sequestration, such species are less suitable for urban areas with heavy traffic volumes. 
The mapping of deviations in $\Delta^{13} \mathrm{C}$ in Kyoto City showed that the leaf $\Delta^{13} \mathrm{C}$ of $R$. pulchrum was small at the area near Kyoto Station (Fig. 4b), which indicates that the long-term intrinsic leaf water use efficiency is higher at the heavy-traffic area. This high water use efficiency at the heavy-traffic area may contribute to enhancing tolerance to air pollution and summer drought. The high long-term water use efficiency at the heavy traffic areas in the present study somewhat contradicts the previous study that reported no distinct relationship between urbanization (population density) and leaf $\Delta^{13} \mathrm{C}$ of annual grasses in Los Angeles, USA (Wang 2010). The discrepancy between studies may be due to the fact that the relationship between urbanization (population density, traffic volumes, etc.) and long-term leaf water use efficiency is affected by the local climate, including soil and atmospheric moisture levels, atmospheric temperature, and $\mathrm{CO}_{2}$ concentration. In the present study, with relatively little variation in the local climate and a large range in the atmospheric pollutants among the study sites, the effect of air pollutants on leaf $\Delta^{13} \mathrm{C}$ may become apparent. In a previous study (Wang 2010), it was found that the effect of urbanization (population density) may be masked by a large difference in the local climate, the difference in VPD in particular.

\section{Conclusions}

Atmospheric $\mathrm{NO}$ and $\mathrm{NO}_{2}$ are important air pollutants that affect the photosynthesis of roadside trees in urban areas. A species-specific response of leaf photosynthesis to air pollution was obtained. Within a single year, the three roadside tree species, $R$. pulchrum, $R$. indica and $P$. yedoensis, had a higher restriction of maximum photosynthesis $\left(A_{\max }\right)$ at the high air pollution sites. On the contrary, the leaf photosynthesis of $G$. biloba was enhanced at high air pollution sites. Non-stomatal limitations are key traits that involved these photosynthetic responses to air pollution within a year. When the data were pooled across the years, the effect of air pollutants on long-term leaf water use efficiency became apparent, in which $\mathrm{NO}$ and $\mathrm{NO}_{2}$ increased the long-term leaf water use efficiency in $R$. pulchrum. It should be noted, however, that we are not able to conclude that $\mathrm{NO}$ and $\mathrm{NO}_{2}$ are the only decisive factors that cause a reduction in $A_{\max }$ and increase in long-term water use efficiency under high pollution levels; some interactions among air pollutants, such as particulate matters and $\mathrm{O}_{3}$, may affect the photosynthetic response of urban trees in Kyoto City. R. pulchrum had a higher restriction in $A_{\max }$ by up to $60 \%$ but had a higher water use efficiency at the heavy traffic areas in Kyoto City, which suggests that $R$. pulchrum has strategies to increase tolerance to air pollution and water limitation at the expense of the leaf photosynthesis rate. This study showed that the air pollution effects on urban trees act both positively and negatively, in which some tree species, such as G. biloba, may grow well even in areas where the effects of automobile exhaust gas are strong.

\section{Declarations}

\section{Acknowledgments}


The leaf stable carbon isotope ratio was measured at the Center for Ecological Research, Kyoto University, and Research Institute for Humanity and Nature. We appreciate Drs. Ichiro Tayasu, Riyo Hirasawa, and Chikage Yoshimizu for supporting the isotope measurements.

Fundings This work was supported by a Grant-in-Aid for Scientific Research (19H04281, 15K00566), the Sumitomo Foundation (103230), and Adaptable \& Seamless Technology Transfer Program through Target-driven R\&D (AS262Z01258N).

Conflict of interest Not applicable.

Availability of data and material Upon request from the authors.

Code availability Not applicable.

\section{Authors contribution}

MM, SY, LK, and YTH planned the experimental design. MM, SY, and LK performed the sample collection and physiological measurements. YTH and TK performed the data analysis. YTH, TK, and AK wrote the manuscript.

Ethic approval Not applicable to this study.

Consent to participate Not applicable to this study.

\section{Consent for publication for publication}

The authors gives Urban Ecosystems consent for publication.

\section{References}

1. Adon M, Yoboué V, Galy-Lacaux C, Liousse C, Diop B, Doumbia EHT, Gardrat E, Ndiaye SA, Jarnot C (2016) Measurements of $\mathrm{NO}_{2}, \mathrm{SO}_{2}, \mathrm{NH}_{3}, \mathrm{HNO}_{3}$ and $\mathrm{O}_{3}$ in West African urban environments. Atmos Environ 135:31-40. https://doi.org/10.1016/j.atmosenv.2016.03.050

2. Brienen RJW, Gloor E, Clerici S, Newton R, Arppe L, Boom A, Bottrell S, Callaghan M, Heaton T, Helama S, Helle G, Leng MJ, Mielikäinen K, Oinonen M, Timonen M (2017) Tree height strongly affects estimates of water-use efficiency responses to climate and $\mathrm{CO}_{2}$ using isotopes. Nat Commun 8:110. https://doi.org/10.1038/s41467-017-00225-z

3. Broeckx LS, Fichot R, Verlinden MS, Ceulemans R (2014) Seasonal variations in photosynthesis, intrinsic water-use efficiency and stable isotope composition of poplar leaves in a short-rotation plantation. Tree Physiol 34:701-715. https://doi.org/10.1093/treephys/tpu057

4. Čada V, Šantrůčková H, Šantrůček J, Kubištová L, Seedre M, Svoboda M (2016) Complex physiological response of Norway spruce to atmospheric pollution-decreased carbon isotope 
discrimination and unchanged tree biomass increment. Front Plant Sci 7:1-12. https://doi.org/10.3389/fpls.2016.00805

5. Dhir B (2016) Air pollutants ad photosynthetic efficiency of plants. In: Kulshrestha U, Saxena P (eds) Plant Responses to Air Pollution. Springer Science + Business Media Singapore, Singapore, pp 7184

6. Drake JE, Power SA, Duursma RA, Medlyn BE, Aspinwall MJ, Choat B, Creek D, Eamus D, Maier C, Pfautsch S, Smith RA, Tjoelker MG, Tissue DT (2017) Stomatal and non-stomatal limitations of photosynthesis for four tree species under drought: A comparison of model formulations. Agric For Meteorol 247:454-466. https://doi.org/10.1016/j.agrformet.2017.08.026

7. Ethier GJ, Livingston NJ (2004) On the need to incorporate sensitivity to $\mathrm{CO}_{2}$ transfer conductance into the Farquhar-von Caemmerer-Berry leaf photosynthesis model. Plant Cell Environ 27:137-153. http://doi.org/10.1111/j.1365-3040.2004.01140.x

8. Fini A, Ferrini F, Frangi P, Amoroso G, Piatti R (2009) Withholding irrigation during the establishment phase affected growth and physiology of norway maple (Acer platanoides) and linden (tilia spp.). Arboric Urban For 35:241-251

9. Flexas J, Barbour MM, Brendelc O, Cabrera HM, Carriquí M, Díaz-Espejo A, Douthe C, Dreyer E, Ferrio JP, Gago J, Gallé A, Galmés J, Kodama N, Medrano H, Niinemets Ü, Peguero-Pina JJ, Pou A, RibasCarbó M, Tomás M, Tosens T, Warren CR (2012) Mesophyll diffusion conductance to $\mathrm{CO}_{2}$ : $\mathrm{An}$ unappreciated central player in photosynthesis. Plant Sci 193-194:70-84. https://doi.org/10.1016/j.plantsci.2012.05.009

10. Grassi G, Magnani F (2005) Stomatal, mesophyll conductance and biochemical limitations to photosynthesis as affected by drought and leaf ontogeny in ash and oak trees. Plant Cell Environ 28:834-849. https://doi.org/10.1111/j.1365-3040.2005.01333.x

11. Grote R, Samson R, Alonso R, Amorim JH, Cariñanos P, Churkina G, Fares S, Thiec D, Le, Niinemets Ü, Mikkelsen TN, Paoletti E, Tiwary A, Calfapietra C (2016) Functional traits of urban trees: air pollution mitigation potential. Front Ecol Environ 14:543-550. https://doi.org/10.1002/fee.1426

12. Grzędzicka $E$ (2018) Is the existing urban greenery enough to cope with current concentrations of PM2.5, PM10 and $\mathrm{CO}_{2}$ ? Atmos Pollut Res 10:219-233

13. Gu X, Wang L, Zhuang W, Han L (2018) Reduction of wheat photosynthesis by fine particulate (PM2.5) pollution over the North China Plain. Int J Environ Health Res 28:635-641. https://doi.org/10.1080/09603123.2018.1499881

14. Hagenbjörk A, Malmqvist E, Mattisson K, Sommar NJ, Modig L (2017) The spatial variation of $\mathrm{O}_{3}$, $\mathrm{NO}, \mathrm{NO}_{2}$ and $\mathrm{NO}_{\mathrm{x}}$ and the relation between them in two Swedish cities. Environ Monit Assess 189: https://doi.org/10.1007/s10661-017-5872-z

15. Hoshika Y, Haworth M, Watanabe M, Koike T (2020) Interactive effect of leaf age and ozone on mesophyll conductance in Siebold's beech. Physiol Plant 170:172-186.

https://doi.org/10.1111/ppl.13121 
16. Hu Y, Bellaloui N, Tigabu M, Wang J, Diao J, Wang K, Yang R, Sun G (2015) Gaseous $\mathrm{NO}_{2}$ effects on stomatal behavior, photosynthesis and respiration of hybrid poplar leaves. Acta Physiol Plant 37: https://doi.org/10.1007/s11738-014-1749-8

17. Ikeda K, Yamaji K, Kanaya Y, Taketani F, Pan X, Komazaki Y, Kurokawa Jl, Ohara T (2015) Source region attribution of PM2.5 mass concentrations over Japan. Geochem J 49:185-194. https://doi.org/10.2343/geochemj.2.0344

18. Iqbal MZ, Shafig M, Qamar Zaidi S, Athar M (2015) Effect of automobile pollution on chlorophyll content of roadside urban trees. Glob J Environ Sci Manag 1:283-296. https://doi.org/10.7508/gjesm.2015.04.003

19. Itahashi S, Uno I, Irie $\mathrm{H}$, Kurokawa Jl, Ohara $\mathrm{T}$ (2014) Regional modeling of tropospheric $\mathrm{NO}_{2}$ vertical column density over East Asia during the period 2000-2010: Comparison with multisatellite observations. Atmos Chem Phys 14:3623-3635. https://doi.org/10.5194/acp-14-3623-2014

20. Jiang J, Aksoyoglu S, Ciarelli G, Baltensperger U, Prévôt ASH (2020) Changes in ozone and PM2.5 in Europe during the period of 1990-2030: Role of reductions in land and ship emissions. Sci Total Environ 741: https://doi.org/10.1016/j.scitotenv.2020.140467

21. Joshi PC, Swami A (2009) Air pollution induced changes in the photosynthetic pigments of selected plant species. J Environ Biol 30:295-298

22. Kagotani Y, Fujino K, Kazama T, Hanba YT (2013) Leaf carbon isotope ratio and water use efficiency of urban roadside trees in summer in Kyoto city. Ecol Res 28:725-734. https://doi.org/10.1007/s11284-013-1056-7

23. Kanda Y (2013) Investigation of the freely available easy-to-use software "EZR" for medical statistics. Bone Marrow Transplant 48:452-458. https://doi.org/10.1038/bmt.2012.244

24. Kim Y, Guldmann J-M (2015) Land-use regression panel models of $\mathrm{NO}_{2}$ concentrations in Seoul, Korea. Atmos Environ 107:364-373

25. Kinoshita T, Kume A, Hanba YT (2021) Seasonal variations in photosynthetic functions of the urban landscape tree species Gingko biloba: photoperiod is a key trait. Trees - Struct Funct 35:273-285. https://doi.org/10.1007/s00468-020-02033-3

26. Kiyomizu T, Yamagishi S, Kume A, Hanba YT (2019) Contrasting photosynthetic responses to ambient air pollution between the urban shrub Rhododendron $\times$ pulchrum and urban tall tree Ginkgo biloba in Kyoto city: stomatal and leaf mesophyll morpho-anatomies are key traits. Trees 33:63-77. https://doi.org/10.1007/s00468-018-1759-z

27. Kume A, Hanba YT, Nakane K, Sakurai N, Sakugawa H (2006) Seasonal changes in needle water content and needle ABA concentration of Japanese red pine, Pinus densiflora Sieb. et Zucc., in declining forests on Mt. Gokurakuji, Hiroshima Prefecture, Japan. J Plant Res 119:231-238. https://doi.org/10.1007/s10265-006-0265-3

28. Kume A, Tsuboi N, Satomura T, Suzuki M, Chiwa M, Nakane K, Sakurai N, Horikoshi T, Sakugawa H (2000) Physiological characteristics of Japanese red pine, Pinus densiflora Sieb. et Zucc., in declined 
forests at Mt. Gokurakuji in Hiroshima Prefecture, Japan. Trees 14:305-311.

https://doi.org/10.1007/PL00009772

29. Lahr EC, Dunn RR, Frank SD (2018) Variation in photosynthesis and stomatal conductance among red maple (acer rubrum) urban planted cultivars and wildtype trees in the southeastern United States. PLoS One 13:1-18. https://doi.org/10.1371/journal.pone.0197866

30. Liu T, Yang X (2013) Mapping vegetation in an urban area with stratified classification and multiple endmember spectral mixture analysis. Remote Sens Environ. doi:https://doi.org/10.1016/j.rse.2013.02.020

31. McCarthy HR, Pataki DE, Darrel Jenerette G (2011) Plant water-use efficiency as a metric of urban ecosystem services. Ecol Appl 21:3115-3127. https://doi.org/10.1890/11-0048.1

32. Medrano H, Flexas J, Galmés J (2009) Variability in water use efficiency at the leaf level among Mediterranean plants with different growth forms. Plant Soil 317:17-29. https://doi.org/10.1007/s11104-008-9785-z

33. Meineke EK, Frank SD (2018) Water availability drives urban tree growth responses to herbivory and warming. J Appl Ecol 55:1701-1713. https://doi.org/10.1111/1365-2664.13130

34. Nowak DJ, Crane DE (2002) Carbon storage and sequestration by urban trees in the USA. Environ Pollut 116:381-389. https://doi.org/10.1016/S0269-7491(01)00214-7

35. Parry C, Blonquist JM, Bugbee B (2014) In situ measurement of leaf chlorophyll concentration: Analysis of the optical/absolute relationship. Plant Cell Environ 37:2508-2520. https://doi.org/10.1111/pce.12324

36. Pataki DE, Randerson JT, Wang W, Herzenach M, Grulke NE (2010) The carbon isotope composition of plants and soils as biomarkers of pollution. Isoscapes Underst movement, pattern, Process Earth through Isot Mapp 407-423. https://doi.org/10.1007/978-90-481-3354-3_19

37. Procházková D, Haisel D, Wilhelmová N, Pavlíková D, Száková J (2013) Effects of exogenous nitric oxide on photosynthesis. Photosynthetica 51:483-489. https://doi.org/10.1007/s11099-013-0053-y

38. Royal Society (2008) Ground-level ozone in the 21st century: future trends. impacts and policy implications

39. Savi T, Bertuzzi S, Branca S, Tretiach M, Nardini A (2015) Drought-induced xylem cavitation and hydraulic deterioration: Risk factors for urban trees under climate change? New Phytol 205:11061116. https://doi.org/10.1111/nph.13112

40. Smith BN, Lytle CM (1997) Air pollutants. In: Prasad MNV (ed) Plant Ecophysiology. John Willey \& Sons, New York, pp 375-392

41. Takagi M, Gyokusen K (2004) Light and atmospheric pollution affect photosynthesis of street trees in urban environments. Urban For Urban Green 2:167-171. https://doi.org/10.1078/1618-866700033

42. Tayasu I, Hirasawa R, Ogawa NO, Ohkouchi N, Yamada K (2011) New organic reference materials for carbon- and nitrogen-stable isotope ratio measurements provided by Center for Ecological Research, 
Kyoto University, and Institute of Biogeosciences, Japan Agency for Marine-Earth Science and Technology. Limnology 12:261-266. https://doi.org/10.1007/s10201-011-0345-5

43. Van Wittenberghe S, Alonso L, Verrelst J, Hermans I, Delegido J, Veroustraete F, Valcke R, Moreno J, Samson R (2013) Upward and downward solar-induced chlorophyll fluorescence yield indices of four tree species as indicators of traffic pollution in Valencia. Environ Pollut 173:29-37. https://doi.org/10.1016/j.envpol.2012.10.003

44. Wang W (2010) Spatial patterns of plant isotope tracers in the Los Angeles urban region. Landsc Ecol 25:35-52

45. Wang Y, Jin W, Che Y, Huang D, Wang J, Zhao M, Sun G (2019) Atmospheric nitrogen dioxide improves photosynthesis in mulberry leaves via effective utilization of excess absorbed light energy. Forests 10: https://doi.org/10.3390/f10040312

46. Wittig VE, Ainsworth EA, Long SP (2007) To what extent do current and projected increases in surface ozone affect photosynthesis and stomatal conductance of trees? A meta-analytic review of the last 3 decades of experiments. Plant Cell Environ 30:1150-1162. https://doi.org/10.1111/j.13653040.2007.01717.x

47. Woo SY, Je SM (2006) Photosynthetic rates and antioxidant enzyme activity of Platanus occidentalis growing under two levels of air pollution along the streets of Seoul. 49:315-319. https://doi.org/10.1007/BF03031162

48. Xu Y, Feng Z, Tarvainen L, Shang B, Dai L, Uddling J (2019) Mesophyll conductance limitation of photosynthesis in poplar under elevated ozone. Sci Total Environ 657:136-145. https://doi.org/10.1016/j.scitotenv.2018.11.466

49. Yang D, Zhang S, Niu T, Wang Y, Xu H, Zhang KM, Wu Y (2019) High-resolution mapping of vehicle emissions of atmospheric pollutants based on large-scale, real-world traffic datasets. Atmos Chem Phys 19:8831-8843. 10.5194/acp-19-8831-2019

50. Yang HI, Park HJ, Lee KS, Lim SS, Kwak JH, Lee S, II, Chang SX, Lee SM, Choi WJ (2018) $\delta^{13} \mathrm{C}, \delta^{15} \mathrm{~N}$, $\mathrm{N}$ concentration, $\mathrm{C} / \mathrm{N}$, and $\mathrm{Ca} / \mathrm{Al}$ of Pinus densiflora foliage in Korean cities of different precipitation $\mathrm{pH}$ and atmospheric $\mathrm{NO}_{2}$ and $\mathrm{SO}_{2}$ levels. Ecol Indic. doi: https://doi.org/10.1016/j.ecolind.2018.01.020

51. Yli-Pelkonen V, Scott AA, Viippola V, Setälä $H$ (2017) Trees in urban parks and forests reduce $\mathrm{O}_{3}$, but not $\mathrm{NO}_{2}$ concentrations in Baltimore, MD, USA. Atmos Environ 167:73-80. https://doi.org/10.1016/j.atmosenv.2017.08.020

52. Zhao Y, Hu Q, Li H, Wang S, Ai M (2018) Evaluating carbon sequestration and PM2.5 removal of urban street trees using mobile laser scanning data. Remote Sens 10: https://doi.org/10.3390/rs10111759

53. Zhong Q, Ma J, Zhao B, Wang X, Zong J, Xiao X (2019) Assessing spatial-temporal dynamics of urban expansion, vegetation greenness and photosynthesis in megacity Shanghai, China during 2000-2016. Remote Sens Environ 233:111374. https://doi.org/10.1016/j.rse.2019.111374 
a

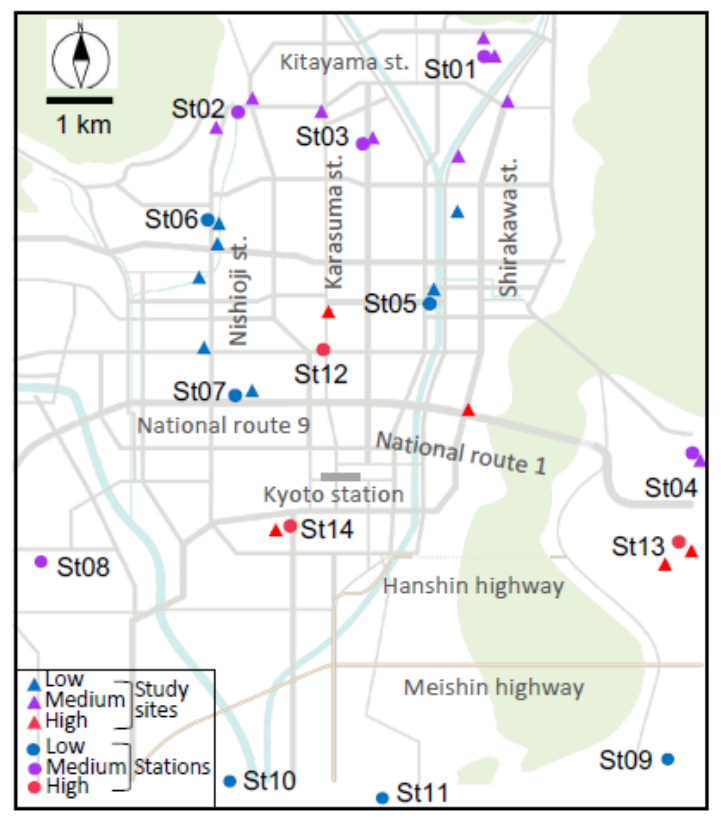

b

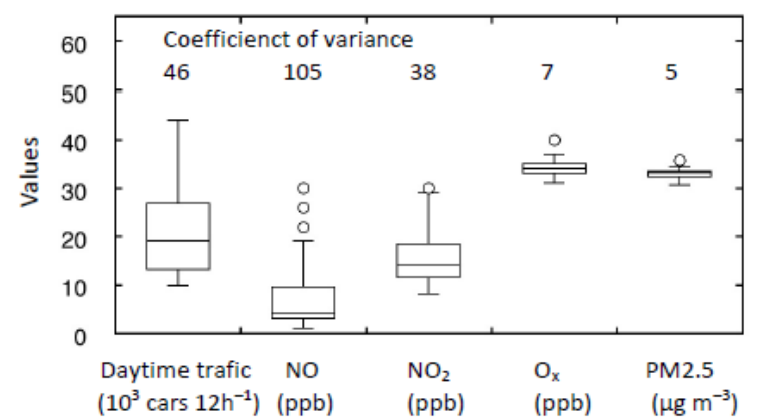

d
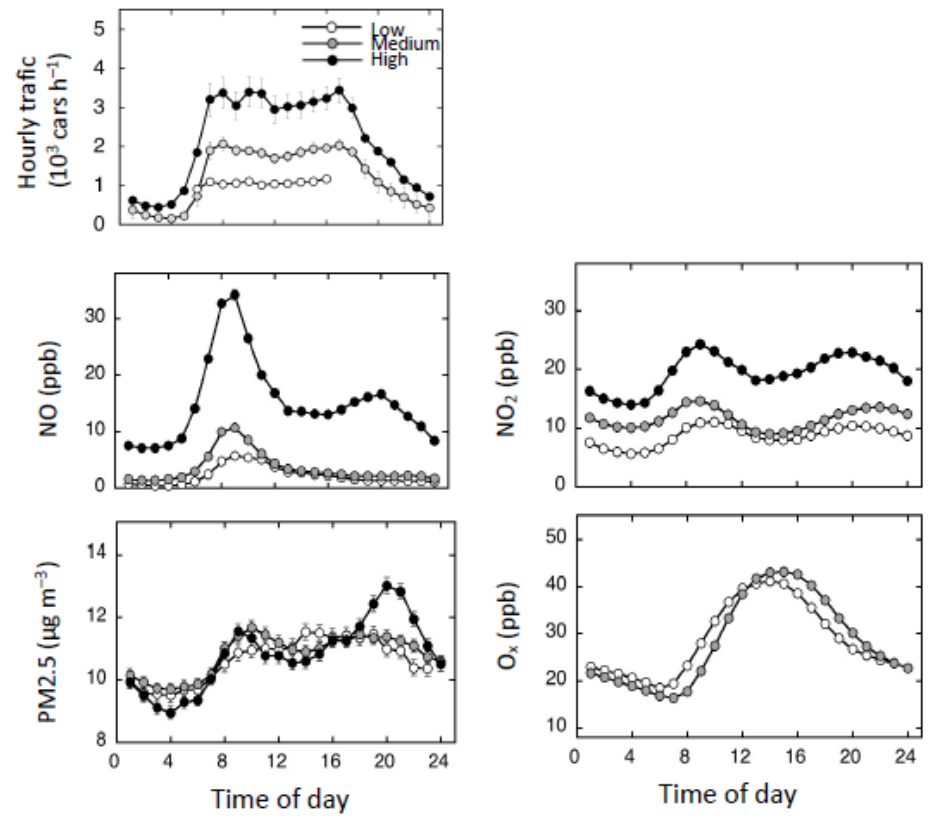

$\mathbf{e}$
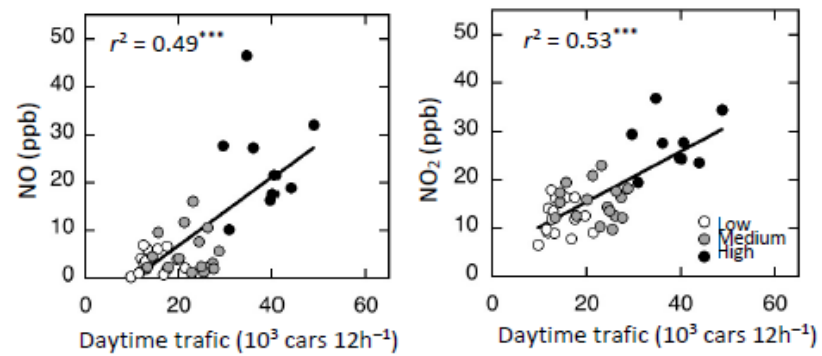

f
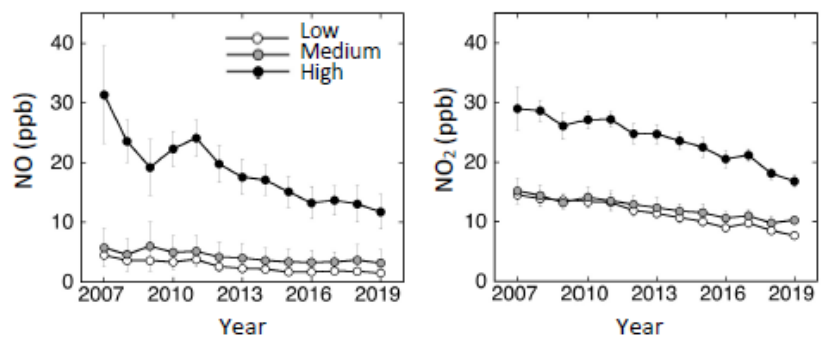

\section{Figure 1}

Study sites and atmospheric pollution levels in Kyoto City. (a) Study sites and 14 monitoring stations for the measurements of atmospheric pollutants (St01 - St14). (b) Box plots for daytime traffic, NO, NO2, Ox, and PM2.5 in the years 2010 and 2015 at the 14 monitoring stations. The annual NO, NO2, Ox, and PM2.5 
data used for the analysis were obtained from April to November. (c) Cluster analysis of the 14 monitoring stations, based on the NO and NO2 levels and traffic volumes in the years 2005, 2010, and 2015 , using the database provided by the Japanese government. Three levels, low-, medium-, and highpollution levels, were detected. (d) Diurnal variations in the atmospheric pollutants, NO, NO2, PM2.5, and Ox, in Kyoto City. Data from the year 2018 were used, which was the means of hourly data from April to November for the three pollution levels $(n=932-1816)$. (e) Dependence of annual NO and NO2 levels on traffic volume. The points represent the means of low-, medium-, and high-pollution levels of each year, in which the data from the years 2005, 2010, and 2015 at the 14 monitoring stations were used $(n=15)$. The annual NO and NO2 data used for the analysis were obtained from April to November. (f) Historical changes of NO and NO2 levels from 2007 to 2019. The points represent the means (se) for low-, medium-, and high-pollution levels, which were calculated using the data from April to November $(n=3-6)$. 
a

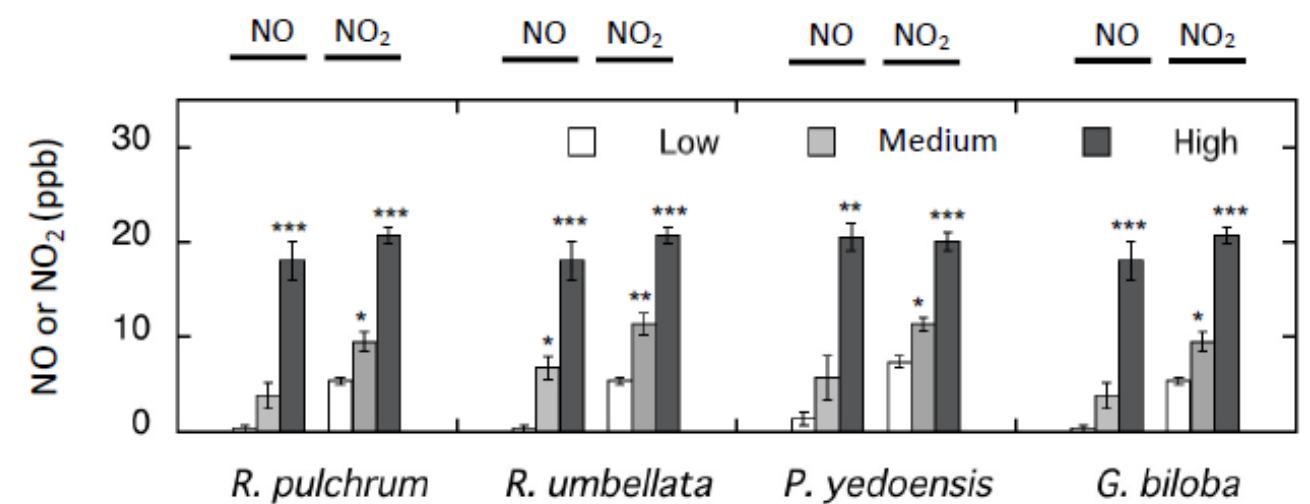

b

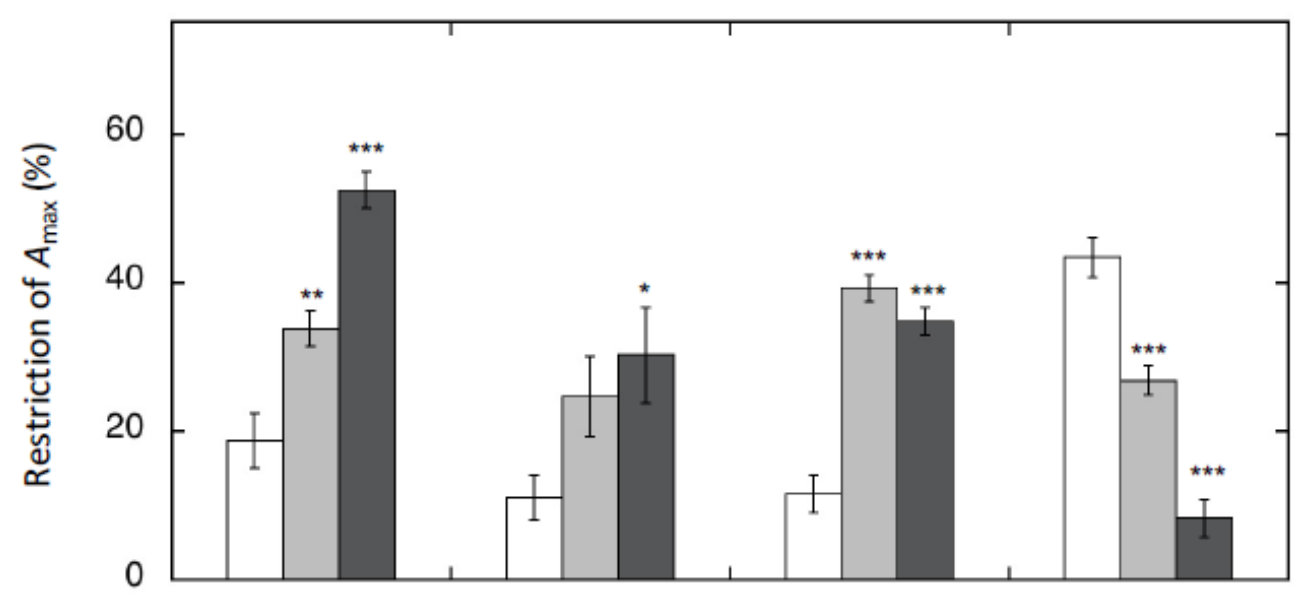

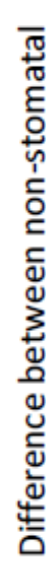
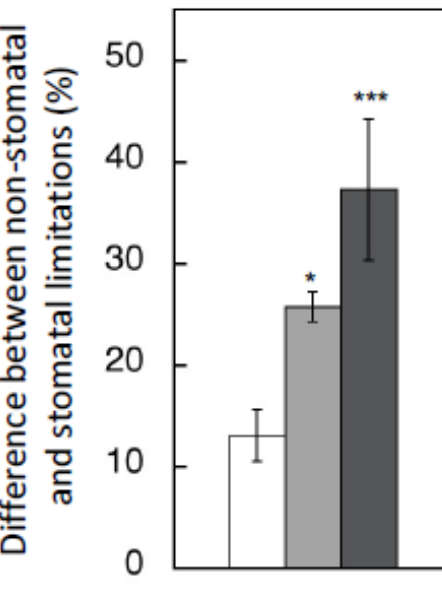

R. pulchrum

R. umbellata

P. yedoensis

G. biloba

\section{Figure 2}

NO and NO2 levels, restriction of Amax, and stomatal and non-stomatal limitations of photosynthesis for the four urban roadside tree species at three different pollution levels. The data were obtained in the year 2016 (P. yedoensis) and 2017 (R. pulchrum, R. indica, and G. biloba). (a) Mean (se) NO and NO2 levels and (b) restriction of Amax and photosynthetic limitations by stomata and non-stomatal capacities. The significance of the difference between pollution levels were tested by ANOVA, Dunnett's test, in which the 
values for the low-pollution level were treated as a control. The significant levels are * $P<0.05$, $* \star P<$ 0.01 , and $* * * \mathrm{P}<0.001$.
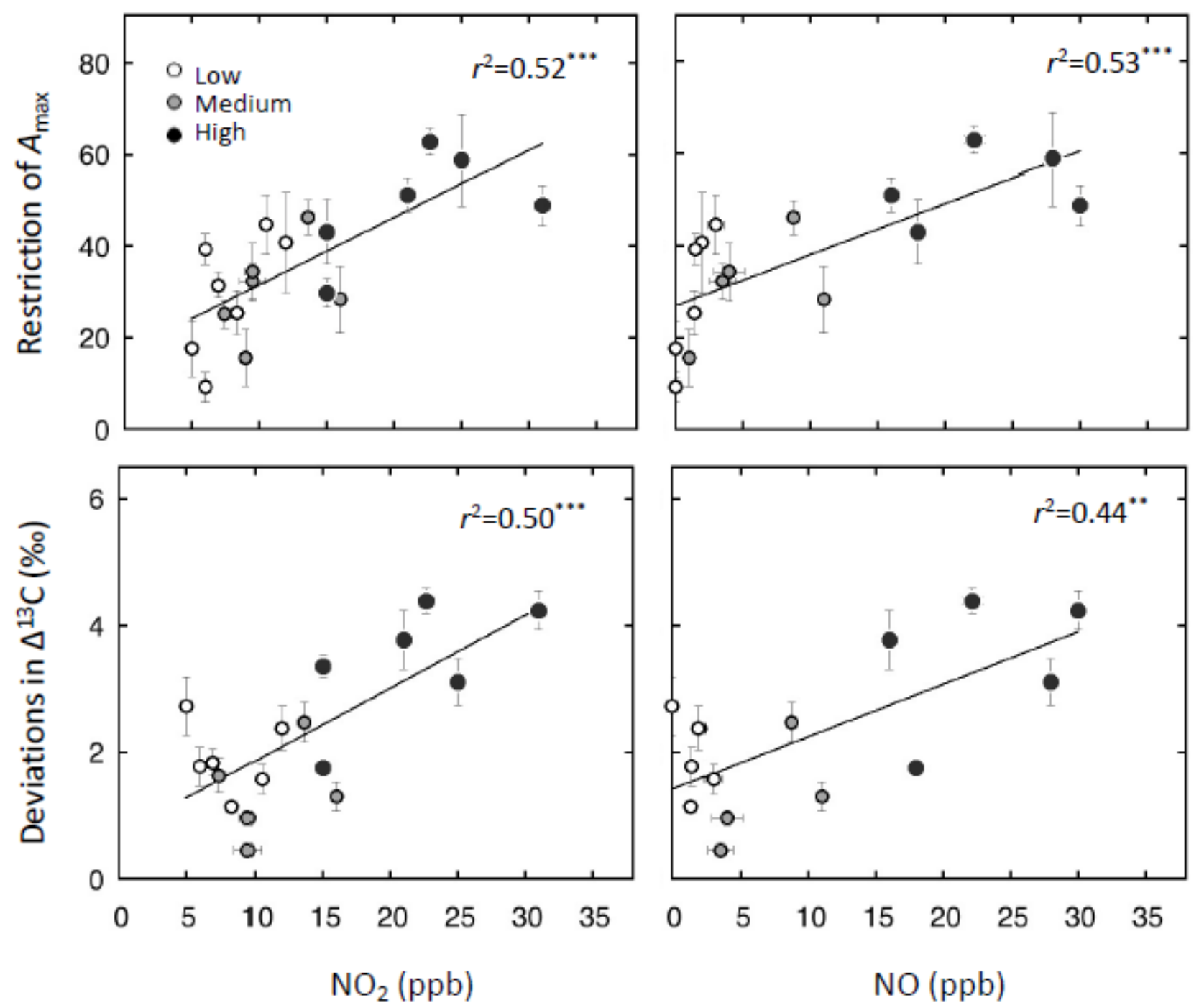

Figure 3

Dependence of photosynthetic variables, restrictions of Amax and deviations in $\triangle 13 \mathrm{C}$ on NO and NO2, for R. pulchrum. The points represent the annual means for $4-35$ leaves from the years 2007 to 2019 , which were collected from low-, medium-, and high-pollution sites $(n=14-19)$. Solid lines indicate regression lines with $r 2$ values and significance of the regression line shown. The significant levels are ** $P<0.01$, and $* * * P<0.001$. Data from the years 2014 and 2015 were redrawn from the published data of our previous study (Kiyomizu et al. 2019). Error bars indicate se values. 


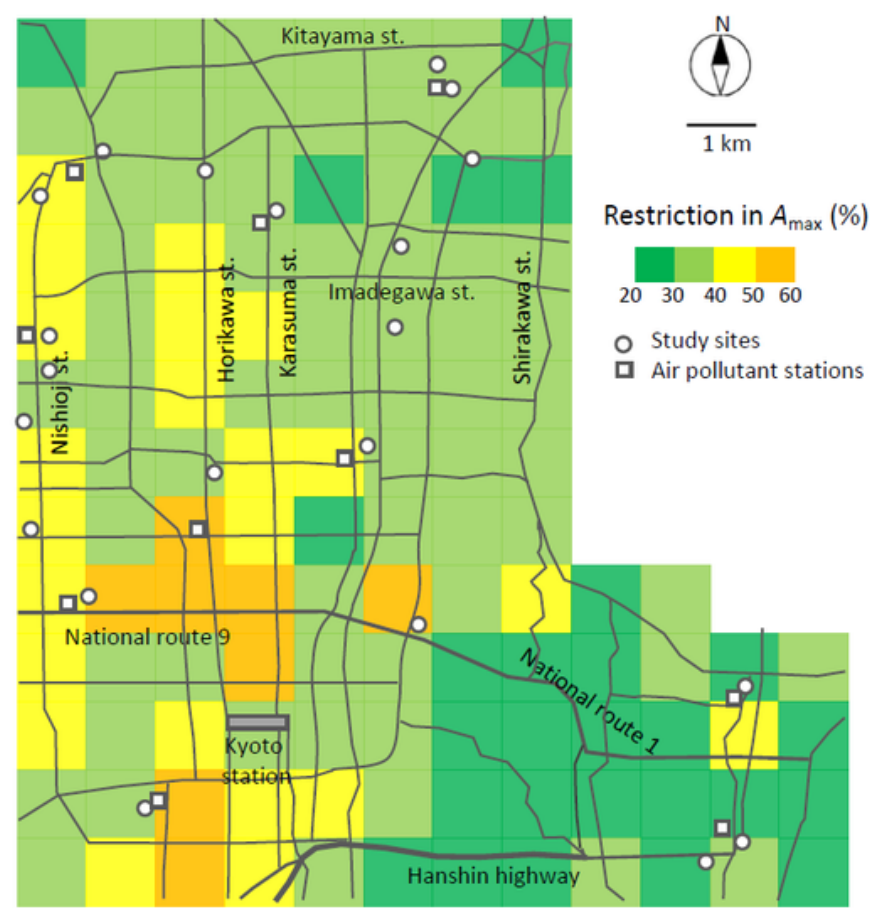

b

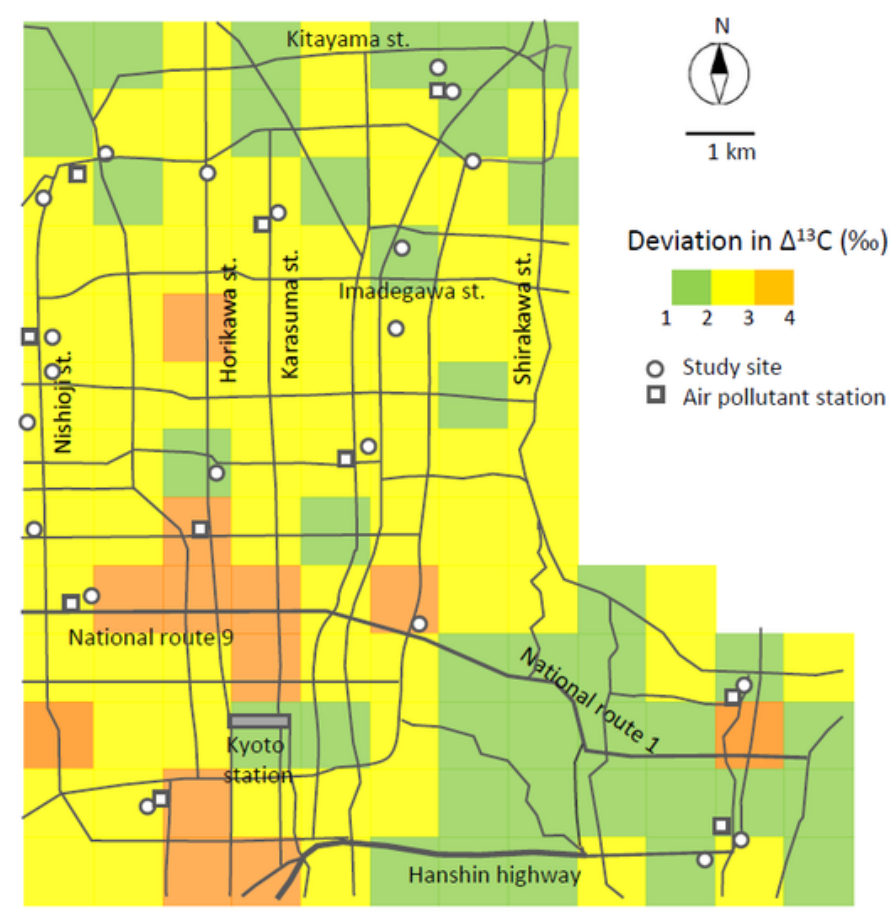

\section{Figure 4}

Maps of restrictions of Amax (a) and deviations in $\triangle 13 \mathrm{C}$ (b) for R. pulchrum in the central area of Kyoto City. The central area of Kyoto City is about 100 km2, and was divided into areas of 1 km2 (122 sections) and then restrictions of Amax and deviation in $\triangle 13 \mathrm{C}$ for each section were estimated using correlations among traffic volumes, NO2, and restrictions of Amax or deviations in $\triangle 13 \mathrm{C}$ (equations 5, 6, and 7 in the text). 


\section{Supplementary Files}

This is a list of supplementary files associated with this preprint. Click to download.

- Matsumoto2021 suppUEC013Jul.docx 